Short communication

\title{
INULIN DIET INTERVENTION ON CHEMOPREVENTIVE AND INFLAMMATORY MARKERS IN TUMORIGENESIS OF COLORECTAL CANCER
}

\author{
HIJOVÁ Emília ${ }^{1 *}$, SZABADOSOVA Viktoria ${ }^{2}$, ŠTOFILOVÁ Jana ${ }^{1}$, SALAJ Rastislav ${ }^{1}$, \\ BOMBA Alojz ${ }^{1}$
}

${ }^{1}$ Institute of Experimental Medicine, Medical Faculty, University of P. J. Šafárik, Košice, Slovak Republic ${ }^{2}$ Faculty of Humanities and Natural Sciences, University of Prešov in Prešov, Prešov, Slovak Republic

(Received 20 March; Accepted 22 April 2014)

\begin{abstract}
The aim of this experiment was to investigate the influence of inulin administration on chemopreventive and inflammatory markers in dimethylhydrazine induced colorectal cancer development in rats. A group of 30 Sprague-Dawley rats was divided into a control group (CG), a group with dimethylhydrazine (DMH), and a group given dimethylhydrazine combined with the prebiotic (DMH+PRE). Dimethylhydrazine injection significantly $(p<0.001)$ elevated the immunoreactivity chemopreventive markers COX-2, NFuB, iNOS, elevated serum and jejunal mucosa levels of proinflammatory cytokine IL-2, and decreased serum and jejunal mucosa levels of regulatory cytokine IL-10. Inulin diet intervention significantly suppressed immunoreactivity of COX2, NFxB, iNOS positive cells in the tunica mucosae and tela submucosae of rat colon tissue, increased levels of IL-2 and decreased levels of IL-10. By determining the chemopreventive markers COX-2, iNOS and NFkB, which can be characterized as inflammatory markers, we confirmed the presence of inflammation in the colon as the number of COX-2, NFkB and iNOS immunoreactive cells was significantly higher after DMH application than in the control group. These findings indicate that dietary intake of inulin suppressed the expression of the observed markers, which play an important role in carcinogenesis and inflammation, which predispose the use of inulin in the prevention or treatment of human chronic diseases and its use as a nutritional supplement in veterinary medicine.
\end{abstract}

Key words: Colon cancer, Sprague-Dawley rats, Inulin, Chemoprevention, Inflammation

\section{INTRODUCTION}

Nowadays, natural substances have been used as alternatives in veterinary medicine with increasing frequency [1,2]. Natural dietary compounds such as prebiotics modulate the microbial composition and ensure a healthy gastrointestinal tract environment, thus they could as potential chemopreventive agents prevent the development colon cancer. An association between the development of cancer and inflammation has long been 
appreciated. Inflammation is now thought to be the key in tumorigenesis via DNA damage, stimulation of the production of pro-inflammatory mediators, angiogenesis, proliferation, and inhibition of apoptosis. Indeed, the link between inflammation and development of colorectal cancer is well-established [3]. Since inflammation is closely linked to tumor promotion, substances with potent anti-inflammatory activities are anticipated to exert chemopreventive effects on carcinogenesis, particularly in the promotion stage. Inflammation may be effectively inhibited by the application of suitable immunomodulators. In this regard by improving the intestinal function and ensuring a healthy gastrointestinal environment prebiotics represent potential natural immunomodulators that attract a great deal of interest in chemoprevention.

Chemoprevention is defined as the use of natural dietary compounds and/or synthetic substances that can delay, prevent, or even reverse the development of adenomas, as well as the progression from adenoma to carcinoma. The ultimate goal of chemoprevention by natural dietary compounds is the reduction of colorectal cancer (CRC) incidence by intervening on the development pathways in tumor cells which promote growth and metastases of CRC [4]. The aim of this study was to determine: (a) the efficacy of the applied prebiotic inulin on the immunoreactivity of cyclooxygenase-2 (COX2), transcription nuclear factor kappa beta $(\mathrm{NF} \varkappa \mathrm{B})$ and inducible nitric oxide synthase (iNOS) in the colon tissue of rats with dimethylhydrazine (DMH) induced colon cancer development; (b) if inulin supplementation could reduce inflammatory markers IL-2 and IL-10 in the blood serum and jejunal mucosa homogenate of rats with DMH induced colon cancer development.

\section{MATERIAL AND METHODS}

\section{Animals and experimental design}

Male and female Sprague-Dawley rats were used in accordance with the principles of the Care and Use of Laboratory Animals and approved by the Ethical Committee of the Faculty of Medicine of P. J. Šafárik University in Košice. Rats were randomly assigned to 3 groups (10 per group): CG control group (with conventional feed), DMH group (received DMH, Merck, Germany at a dose of $21 \mathrm{mg} / \mathrm{kg}$ body weight subcutaneously five times with weekly intervals and conventional feed) and DMH+PRE group (received conventional feed, DMH and oligofrucose-enriched inulin, BeneoSynergy 1, ORAFTI, Tienen, Belgium at a dose of $80 \mathrm{~g} / \mathrm{kg}$ of conventional feed). After 7 months of trial the rats were euthanized under anesthesia (Ketamine 100mg/kg + Xylazine $15 \mathrm{mg} / \mathrm{kg}$ body weight, i.p.) blood samples were taken by cardiac puncture and tissue samples were taken from the jejunum and colon.

\section{Assessment of cytokine levels in the blood serum and jejunal homogenates}

The serum levels of interleukins (ILs), IL-2 and IL-10 were measured by ELISA (eBioscience, USA) according to the manufacturer's directions. The segment of the 
jejunum was taken, flushed with ice-old PBS ( $\mathrm{pH}$ 7.2) solution, opened longitudinally. The frozen scraped jejunal mucosa was homogenized with a homogenizer in PBS solution and centrifuged at $12,000 \mathrm{~g}$ for $20 \mathrm{~min}$. at $4^{\circ} \mathrm{C}$. The supernatant was collected and used in order to measure levels of IL- 2 and IL-10 according to the instructions provided by the ELISA kits manufacturer.

\section{Immunohistochemical analysis of the chemopreventive markers COX-2, NFx B, iNOS in the colon tissue}

Immunohistochemical staining of markers $\mathrm{COX}-2, \mathrm{NF} x \mathrm{~B}$ and $\mathrm{iNOS}$ in the colon tissue was performed on 4-5 $\mu \mathrm{m}$ paraffin sections using a commercial kit HRP-DAB Cell \& Tissue Staining Kit (R\&D Systems, UK). Immunoreactivity in the tunica mucosae and in the tela submucosae of the colon was localized by immunohistochemistry using specific anti-COX-2 antibodies (diluted 1:500; Abcam, UK), anti-NFxB (diluted 1:100; MBL International, USA) and anti-iNOS (diluted 1:5000; Sigma Aldrich, Czech Republic). Immunoreactivity of $\mathrm{COX}-2, \mathrm{NF} x \mathrm{~B}$ and $\mathrm{NOS}$ was expressed as the total number (average of tunica mucosae and tela submucosae) of positive cells calculated to the area of $1000 \mu \mathrm{m}^{2}$ tissue of the colon.

\section{Statistical analysis}

Results are expressed as mean \pm standard deviation (SD). Statistical analysis was performed using analysis of variance (ANOVA) with $p$ values $(\mathrm{p}<0.05)$ considered to be statistically significant.

\section{RESULTS AND DISCUSSION}

Our results indicate that undigested food such as prebiotics fermented in the colon by the microbiota give rise to various microbial metabolites mainly short-chain fatty acids (SCFA), including acetic, propionic and butyric acid [5]. Propionic acid is produced by fermentation of polysaccharides and oligosaccharides by the anaerobic colonic microbiota. It has a moderate inhibitory activity on cyclooxygenase, hence the direct anti-inflammatory effect of propionic acid via cyclooxygenase is to be expected and this is (or could be) a likely mechanism for the down-regulation of low-grade mucosal inflammation by prebiotic diets.

Enhanced expression of COX-2, which is an important enzyme that mediates inflammatory processes, has been observed in many different types of tumors and transformed cells [6]. The provided proof is the finding of the highest total number of COX-2 positive cells in the colon tissue in the DMH group with induced colon cancer development (Figure 1). Similar changes in the DMH group were recorded in the total numbers of NFKB and iNOS positive cells in the colon tissue $(p<0.001)$. The increased concentrations of proinflammatory cytokine IL-2 and the suppressed levels of the regulatory cytokine IL-10 in DMH group are associated with chronic inflammation which is closely linked to tumor promotion (Figure 2). 


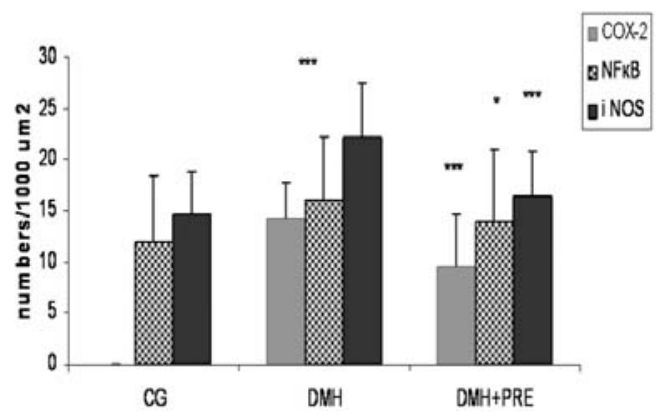

Figure 1. COX-2, NFkB and iNOS total numbers of positive cells in colon tissue. Statistical significance is comparison CG/DMH and DMH/DMH+PRE, ${ }^{*} \mathrm{p}<0.05$, ${ }^{* * *} \mathrm{p}<0.001$
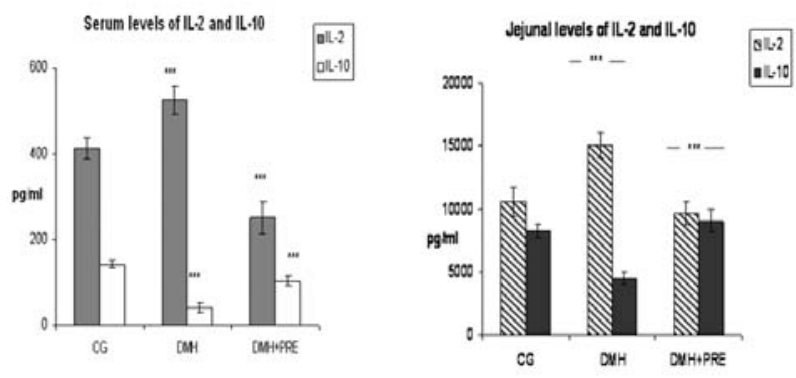

Figure 2. Serum and jejunal IL-2 and IL-10 levels. Statistical significance is comparison CG/DMH and DMH/DMH+PRE, ${ }^{* * *} \mathrm{p}<0.001$

Dietary supplementation with the prebiotic inulin reduced the inflammatory response present in the serum and jejunal mucosa by inhibiting the production of the pro-inflammatory IL-2 and stimulating the regulatory IL-10 which shows its antiinflammatory activity and immune enhancing effect [7]. The applied inulin decreased the total numbers of $\mathrm{COX}-2, \mathrm{NF} \varkappa \mathrm{B}$ and iNOS positive cells (COX-2: NFxB $\mathrm{r}=0.583$; NFuB:iNOS $\mathrm{r}=0.939)$. Recent studies demonstrated that the regulation of COX-2 involves the transcription nuclear factor-kappa beta (NFxB) [8]. Several chemopreventive phytochemicals have been shown to inhibit COX-2 by blocking improper $\mathrm{NF} x \mathrm{~B}$ activation. The transcriptional activity of $\mathrm{NF} x \mathrm{~B}$ is regulated via an elaborate series of intracellular signal tranduction events in response to external stimuli such as mitogens and inflammatory cytokines [9]. In addition to its central role in mediating inflammation, $\mathrm{NF} x \mathrm{~B}$ is important in controlling cell proliferation, oncogenesis and cell transformation and has drawn much interest as an attractive therapeutic target for novel anti-inflammatory and immunomodulatory drugs [10]. Inactivation of $\mathrm{NFkB}$ in tumor processes supports the reduction of the incidence and size of tumors [11]. The effect of prebiotics on the activity of NFkB is affected by butyric acid. Changing the composition of the microflora also affects the activation 
of $\mathrm{NFkB}$, for example Eubacterium and Bifidobacterium are able to inactivate $\mathrm{NFkB}$. The enzyme activated through $\mathrm{NFkB}$ that plays a pivot role in mediating inflammation especially when it interacts with COX-2 is iNOS. It is beleived that chronic inflammation and repeated production of NO by iNOS leads to neoplastic transformation, a key step in the process of carcinogenesis. Increased expression of iNOS in DMH-induced group was probably due to a positive regulation of the NOS2 gene, which codes iNOS [12].

\section{CONCLUSION}

By determinig COX-2, iNOS and NFkB which can be characterized as good targets for chemoprevention of colon cancer as well as inflammatory markers, we confirmed the presence of inflammation in the colon. The number of COX-2, NFkB and iNOS immunoreactive cells was significantly higher after DMH application than in the control group [13]. All detected changes were also seen in others studies on DMHinduced carcinogenesis in rats, but also in carcinogenesis in humans and confirm that activation of inflammatory signaling pathways are influenced by $\mathrm{DMH}$ and are the evidence of the interaction of chronic inflammation with carcinogenesis. Inulin supressed the expression of the observed markers, thus predisposing the use of inulin in the prevention or treatment of human chronic diseases and promoting inulin as a nutritional supplement in veterinary medicine.

\section{Acknowledgments}

This work was supported by the Slovak Scientific Agency VEGA (No 1/0372/10) as well as by Agency of the Slovak Ministry of Education for the Structural Funds of the EU, under ITMS 26220120058 (30\%), and ITMS 26220220104 (30\%).

\section{REFERENCES}

1. Hijová E, Chmelárová A, Bomba A, Žitňan R: Prebiotic foodstuff and their health benefits in experiment. Bratisl Lek Listy 2009,110: 523-525.

2. Lauková A, Strompfová v, Simonova M, Skrivanova V, Volek Z, Haviarova M et al.: Probiotic and bacteriocinogenic microorganisms in rabbit breeding. In: Proc. VII Days of Nutrition and Veterinary Dietetics 2006, Košice, Slovak Republic, 100.

3. Danese S, Mantovani A: Inflammatory bowel disease and intestinal cancer: a paradigm of the Yin-Yang interplay between inflammation and cancer. Oncogene 2010, 29: 3313-3323.

4. Pan MH, Ho CT: Chemopreventive effects of natural dietary compounds on cancer development. Chem Soc Rev 2008, 37: 2558-2574.

5. Wong JM, deSouza R, Kendall CW, Emam A, Jenkins DJ: Colonic health: fermentation and short chain fatty acids. J Clin Gastroenterol 2006, 40: 235-243. 
6. Sano H, Kawahito Y, Wilder R, Hashiramoto A, Mukai S, Asai K, Kimura S, Kato H, Kondo M, Hla T: Expression of cyclooxygenase -1 and -2 in human colorectal cancer. Cancer Res 1995, 55: 3785-3789.

7. Schley PD, Field CJ: The immune-enhancing effect of dietary fibres and prebiotics. Br J Nutr 2002, 87: 221-230.

8. Bakhle YS: COX-2 and cancer: a new approach to an old problem. Br J Pharmacol 2001, 134: 1137-1150.

9. Chen F, Castranova V, Shi X, Demers LM: New insights into the role of nuclear factor- $x \mathrm{~B}$, a ubiquitous transcription factor in the iniciation of diseases. Clin Chem 1999, 45: 7-17.

10. Chabot-Fletcher M: Transcription factor NFxB: an emerging anti-inflammatory drug target. Pharmacol Rev Commun 1996, 8: 317-324.

11. Kundu JK, Surh YJ: Inflammation: gearing the journey to cancer. Mutat Res 2008, 659: 15-30.

12. Femia AP, Luceri C, Toti S, Giannini A, Dolara P, Caderni G: Gene expression profile and genomic alterations in colonic tumours induced by 1,2-dimethylhydrazine (DMH) in rats. BMC Cancer 2010, 10: 1-13.

13. Watanabe K, Kawamori T, Nakatsugi S, Wakabayashi K: COX-2 and iNOS, good targets for chemoprevention of colon cancer. Biofactors 2000, 12: 129-133.

\title{
ISHRANA INULINOM KAO TERAPIJA NA HEMOPREVENTIVNE I ZAPALJENSKE MARKERE TUMOROGENEZE KOLOREKTALNIH KANCERA
}

\author{
HIJOVÁ Emília, SZABADOSOVA Viktoria, ŠTOFILOVÁ Jana, SALAJ Rastislav, \\ BOMBA Alojz
}

Obavljeno je ispitivanje uticaja davanja inulina na hemopreventivne i zapaljenske markere kod kolorektalnih kancera izazvanih dimetilhidrazinom kod pacova. Ukupno je 30 Sprague-Dawley pacova podeljeno na kontrolu grupu (CG), dimetilhidrazin grupu (DMH) i grupu koja je primila dimetilhidrazin zajedno sa prebiotikom (DMH+PRE). Injekcija dimetilhidrazina je značajno $(\mathrm{p}<0.001)$ povećavala imunoreaktivnost hemopreventivnih markera $\mathrm{COX}-2, \mathrm{NF} \varkappa \mathrm{B}$, iNOS, povećavajući koncentracije proinflamatornih citokina IL-2 u serumu i jejunalnoj mukozi uz smanjenje koncentracije regulatornih citokina IL-10 u serumu i jejunalnoj mukozi. Davanje inulina u hrani, značajno je suprimiralo imunoreaktivnost COX-2, NFxB i iNOS pozitivnih ćelija u tunica mucosae i tela submucosae tkiva kolona pacova, povećavajući koncentracije IL-2 i smanjujući koncentracije IL-10. Određujući hemopreventivne markere COX-2, NFxB i iNOS, koji mogu da se definišu i kao zapaljenski markeri, potvrdili smo prisustvo zapaljenske reakcije u kolonu s obzirim da je broj COX-2, NF^B i iNOS imunoreaktivnih ćelija bio značajno povećan posle aplikacije DMH u poređenju sa kontrolnom grupom. Rezultati ukazuju da davanje inulina u hrani vrši supresiju ekspresije posmatranih mar- 
kera koji imaju značajnu ulogu u karcinogenezi i zapaljenskoj reakciji, što ukazuje da inulin ima značajnu ulogu u prevenciji ili terapiji hroničnih oboljenja kod ljudi kao i da je važna primena inulina kao dodatka u ishrani u veterinarskoj medicini. 